\title{
The role of slow design elements in managing tourist flow on the example of Bruges, Belgium
}

\author{
BRIgitTa PÉCSEK ${ }^{1}$
}

\begin{abstract}
This paper attempts to rethink the tourist flow from the perspective of urban planning solutions, which have potentials of slowing down tourists and dispersing them more evenly in urban areas. It starts with an overview on current urban tourism trends and challenges and with a cross-disciplinary approach the wider contemporary literature is introduced including citta slow and slow design. The focal point of the analytical part of the paper is the historic city of Bruges and the analysis of its green spaces, land and water related structures that influence tourist mobility. The paper argues that heritage towns like Bruges are not without tools to cope with the tourist 'overflow' and more awareness of tourists' space usage coupled with sound planning might even boost their efficiency to do so. The study also aims to enrich the intellectual debate on slow perspectives and practices in order to help urban destinations manage successfully spatial-temporal crowd movement.
\end{abstract}

Keywords: urban tourism, urban design, slow design, citta slow, Bruges

\section{Introduction}

The main aim of this paper is to present the role of urban design, specifically green spaces, land and water related structures in the management of the tourist flow. There is a growing body of literature focusing on urban tourism (Biczó, G. 2011; Jensen, O.B. 2009; Michalkó, G. and RÁtz, T. 2006; Puczkó, L. and Rátz, T. 2003; Senneth, R. 1994; Szijártó, Zs. 2011), where both the supply and the demand sides of urban tourism are intensely discussed. There has also been a proliferation of research regarding crowd management in urban settings (Bryon, J. 2005; Bryon, J. and Neuts, B. 2008; Popp, M. 2011; Selby, M. 2004). However, the relationship between cities' layout and tourist interactions within the context of tourists' mobility has been widely neglected. Since each destination has its own spatial and temporal pattern influenced by landscape and architecture, directly impacting tourist circulation, this theoretical hiatus should be filled.
Cities, the clearest manifestations of turbo capitalism, serve as residential, industrial and commercial areas for locals, while being the epicentre of global urban tourism. Consequently, they have always been a battle-ground where locals and tourists stake their claims. Pausianus (160 B.C.), a seasoned traveller of his time penned the first ever baedeker, in which he designed a 2-5 year long "ancient" Grand Tour, including Rome, Greece, Turkey and Egypt in the itinerary (Oldfield, P. 2013). Later in the $17^{\text {th }}$ century the classical Grand Tour meant something very similar, a traditional trip of Europe undertaken by wealthy upper-class young European men. Today, cities are easily accessed by both low-cost airlines and superfast trains, therefore, they have become a paradise for weekend travellers. In cities local residents and visitors are intimately linked by motion and have to negotiate their relationship on a daily basis (JENSEN, O.B. 2009). What is more intriguing that tourists themselves fight for the same congested space.

\footnotetext{
${ }^{1}$ Enyedi György Doctoral School of Regional Sciences, Szent István University, H-2100 Gödöllő, Páter Károly u. 1. E-mail: brigitta.pecsek@gmail.com
} 
This paper starts with an overview of contemporary literature on urban tourism, followed by the discussion of the citta slow initiative drawing upon works of renown international experts (Honoré, C. 2005; Dickinson, J.E. et al. 2010; KNOx, P. 2005; LumsDon, L. and McGrath, P. 2010), moving onto the description of the slow design concept put forward by Strauss, C. and Fuad-Luke, A. (2008).

The theoretical part is followed by a casestudy on Bruges which illustrates how urban design can rearrange the tourist flow in terms of space and time. The paper argues that heritage towns like Bruges are not without tools to cope with the tourist 'overflow' and more awareness and careful planning might even boost their efficiency to do so. The town boasts landscape solutions, water related structures including canals, bridges and quays rebuilt for pedestrian traffic as well as built structures such as passages and towers, which all might influence space consumption pattern. These design solutions slow down movements, break the rhythm, and initiate pause, reflection and engagement that contribute to slower tempo and more rewarding participatory experiences. The ultimate goal of the study is to draw attention to existing urban design solutions that impact urban tourist flows and to generate an intellectual brainstorming among urban geographers, social scientists and tourism planners.

\section{Urban tourism}

The World Tourism Organization (UNWTO) refers to urban tourism as trips taken by travellers to cities or places of high population density. The duration of these trips is usually short (1-3 days), therefore, it can be said that urban tourism is closely linked to the short-breaks market (Tourism 2020 Vision, UNWTO 2002). Urban tourism is booming all over the world. The Euromonitor survey indicates that out of the 20 most visited cities in the world, only two (Antalya and Shanghai) suffered a slight loss of arrivals from 2011 to 2012 (Table 1).
The former is the capital of the Mediterranean coast in Turkey, and unlike the cosmopolitan Istanbul, it is a transportation hub for international package tourists heading to Mediterranean resorts. Shanghai, the great regional business centre also lost 2 percent of its visitors, however, other Chinese cities such as Shenzhen and Guangzhou compensated for the loss with a growth of 9.6 percent and 1.2 percent respectively. The top 20 list contained 12 Asian and 4 European cities, plus the Eurasian Istanbul, New York as the only American representative, and Dubai with Mecca, both located on the Arabian Peninsula. No African, South American and Australian cities appeared on the list in 2012.

The survey clearly shows a definite shift from Europe-centred tourism towards a more Asia-centred one. The first five positions were exclusively occupied by Asian cities except for London. The most substantial growth was realised in Taipei, Istanbul, Bangkok and Rome, each enjoyed over a 10 percent increase in one year. Apart from China, Turkey and Thailand also had multiple participants: Istanbul and Antalya, Bangkok and Pattaya respectively. In both cases the second city is a hub for SSS (sea, sun, sand) tourists. Only Mecca, the Islamic holy city is a religious centre. Prague was the only representative of Central and Eastern Europe on the list. Overall, it might be concluded that cities enjoyed a robust growth in the examined period, however, Southeast Asia and Western Europe had by far the highest concentration of tourists.

Urban tourism became subject of academic interest during the 1980s. The recent emergence of low cost airlines contributed to a robust growth in the field and increased the interest of researchers even further. PuczKó, L. and RÁtz, T. (2003) argued that the attraction of cities is due to the fact that as complex, sophisticated tourism products they appeal to a broader market. Metropolitan areas possess a high concentration of sights, therefore, they represent an unmatchable good value in contemporary mass tourism. This density of attractions produces a great synergy effect and makes urban destinations less prone to 
Table 1. Euromonitor International's top city destinations ranking in 2012

\begin{tabular}{c|l|l|c|c}
\hline Rankings & \multicolumn{1}{|c|}{ City } & \multicolumn{1}{c}{ Country } & $\begin{array}{c}\text { Arrivals in } 2012 \\
1,000 \text { persons }\end{array}$ & $\begin{array}{c}\text { Growth from } 2011 \text { to } \\
2012 \text { in } \%\end{array}$ \\
\hline 1. & Hong Kong & China & $23,770.2$ & 6.5 \\
2. & Singapore & Singapore & $21,345.7$ & 7.7 \\
3. & Bangkok & Thailand & $15,822.6$ & 14.6 \\
4. & London & UK & $15,461.0$ & 2.3 \\
5. & Macau & China & $13,360.8$ & 3.4 \\
6. & Kuala Lumpur & Malaysia & $13,339.5$ & 6.7 \\
7. & Shenzhen & China & $12,100.4$ & 9.6 \\
8. & New York City & USA & $11,618.0$ & 8.9 \\
9. & Antalya & Turkey & $10,296.6$ & -1.6 \\
10. & Paris & France & $9,780.8$ & 3.3 \\
11. & Istanbul & Turkey & $8,820.1$ & 16.5 \\
12. & Rome & Italy & $8,670.7$ & 13.9 \\
13. & Dubai & UAE & $8,023.0$ & 0.5 \\
14. & Guangzhou & China & $7,879.6$ & 1.2 \\
15. & Phuket & Thailand & $7,217.0$ & 14.7 \\
16. & Mecca & Saudi Arabia & $6,852.9$ & 6.9 \\
17. & Pattaya & Thailand & $6,564.3$ & 8.4 \\
18. & Taipei & Taiwan & $6,561.2$ & 24.8 \\
19. & Prague & Czech Republic & $6,547.7$ & 5.1 \\
20. & Shanghai & China & $6,539.7$ & -2.2 \\
\hline
\end{tabular}

Source: Euromonitor, 2013.

seasonality. The phenomenon is also reinforced by the birth and spread of the experience economy theorized by (PINE, P.J. and GILmoRE, J.H. 1999), which has been gradually replacing the traditional service economy.

Michalkó, G. and Rátz, T. (2006) pointed out that simultaneously with the urban tourism boom, a falling demand in seaside holidays might also be noticeable, since an SSS holiday with a narrower range of offerings cannot compete with historic cities, which are considered by many as the genuine temporal manifestations of the days gone by. As the source of holiday satisfaction is coming more often than not from the tourists' narrative constructed through the interpretation of experiences instead of the physical resources, cities with vibrant cultures will always have comparative advantages.

Biczó, G. (2011) picks upon the aspects of familiarity, saying that urban tourism provides less challenge to visitors who are mostly city dwellers themselves, even though leaving their residence behind always represents some risks. So, the primary motive of urban tourists is not necessarily to yearn for the unknown and exotic but to find an exit from daily drag and schedule.

According to SzIJÁrTó, Zs. (2011) getting off the treadmill and the relaxation of the brain are the main points of tourism. After getting into the holiday spirit, the hustle and bustle of the destination is no cause for concern anymore. On the contrary, for happy nonparticipants witnessing locals succumbing to hurry might even be a joyful experience.

NiedermüLler, P. (2000) also supports the point by saying that urban tourism for city dwellers is a mish-mash of the well-known and the unknown, since each city has familiar non-places such as movies or bankomats, the everyday and the profane, where tourists feel at home and ease. He joins Biczó and SzIJÁRTó arguing that urban tourism does not display exoticism, even though each city is a representation of the national culture and always will be distinguishable.

Due to the popularity of city breaks, local governments, urban planners and designers face an unprecedented challenge. According 
to the World Health Organization (WHO) 50 percent of the world population ( 3.5 billion) lived in cities in 2010. The Global Report of City Tourism (2012) estimates that the urban population continues to grow and will reach 61 percent worldwide in 2030, so close to five billion people will live in urban areas. The growth of cities will take place alongside with the further expansion of urban tourism. The report identifies the following set of issues in relation to urban tourism:

- How to manage the increasing number of tourists arriving to cities in a responsible and sustainable way?

- How to use urban tourism to improve the quality of life of the local population?

- How can we make sure that tourism action plans and the city development are part of the decision making process?

- How can we incorporate available information and communication technologies to develop smart cities that are more competitive, sustainable, accessible and human?

- How to measure the economic impact of tourism for the cities?

- How can cities take practical steps to reduce impact on the environment and promote the benefits of greener tourism?

\section{Slow cities}

The first grassroots initiative, the slow food was launched by the Italian Carlo Petrini in Pollenzo in 1984 to protest against the opening of a McDonald's restaurant in Rome. Nowadays, it has followers in 150 countries where locals and visitors enjoy the pleasure of food in a sustainable and responsible way. Slow Food dreams of a world, in which all people can access and enjoy healthy food, which is also good for those who grow it and for the planet as well. They fight against the standardisation of taste and culture, and the omnipotent power of food industry multinationals and industrial agriculture. Their approach is based on three main principles: good, clean and fair food (www.slowfood.com).
The citta slow ("slow city") movement (1999) is built upon the slow food ideology and principles to counteract the superfast pace of megacities. SENNETH, R. (1994) argues that fast mobility in cities destroys the sense of place and the function of urban space degenerates into nothing else than providing smooth traffic flow. The citta slow movement born at the advent of the millennium aims to give a viable alternative for those who enjoy the perks of the cities (heritage and culture) without the fast space and pollution. It results in the improvement of the quality of life and well-being for locals. Those urban areas create ideal conditions for slow tourism, because a growing number of travellers find the promise of the slower pace attractive.

A lot of towns worldwide have embraced careful urban planning in order to make the place equally enjoyable for locals and visitors alike. However, the movement is only open to towns with a population of less than 50,000. Larger cities need to rethink their spatial and temporal framework by breaking up urban areas into smaller fragments. МiснаLкó, G. (2012) defines them as distinct neighbourhoods milieus, while SzIJÁrTó, Zs. (2004) calls them coulisses. These fragmented metropolises then allow visitors to interact with locals, consume local products, enjoy local culture just as much as close-knit country communities do.

The goals of the movement include improving the quality of life in towns by slowing down its overall tempo. There are three categories of membership: citta slow town (population less than 50,000); citta slow supporter (population over 50,000); and citta slow friend (individual or family). In 201428 countries had 176 slow cities situated mainly in Europe, however, some of them are located in Canada or New Zealand. Larger cities can become either a supporting member or can transform a certain district of the metropolitan area into a slow city (e.g. Jeonju Hanok district in Jeonju). To become eligible for full membership, a town must score at least 50 percent in a self-assessment test against the set of 55 citta slow criteria centred on the following 6 issues: 
1. making life better for everyone living in an urban environment,

2. improving the quality of life in the cities,

3. resisting the homogenisation and globalisation of towns around the globe,

4. protecting the environment,

5. promoting cultural diversity and uniqueness of individual cities,

6. providing inspiration for a healthier lifestyle (www.cittaslow.com).

An ever-growing number of destinations implement a variety of citta slow principles in order to enhance the quality of everyday life and to manage the circulation of both locals and tourists more effectively. The following sections present the case of Bruges taking a so far neglected angle, the relationship between urban design and the tourist flow.

\section{Tourism in Bruges}

Flemish art cities are considered to be the most attractive tourism products in Belgium and enjoy a dynamic growth in tourism. Data show the latest statistics on urban tourism in the region's six main urban destinations (Table 2).

Table 2. Tourism in Flemish cities in 2012

\begin{tabular}{l|c|c}
\hline Cities & $\begin{array}{c}\text { Overnight stays, } \\
\text { million guest } \\
\text { nights }\end{array}$ & $\begin{array}{c}\text { Distribution of } \\
\text { overnight stays, } \\
\%\end{array}$ \\
\hline Brussels & 6.0 & 55 \\
Antwerp & 1.8 & 16 \\
Bruges & 1.6 & 16 \\
Ghent & 0.9 & 8 \\
Leuven & 0.4 & 3 \\
Mechelen & 0.2 & 2 \\
\hline
\end{tabular}

Source: Toerismevlaanderen 2013.

Capital cities are the crown jewels of citybreaks. So, not surprisingly, Brussels was by far the most popular destination in 2012, concentrating five million overnight stays in 2008, which went up gradually to over 5.6 million nights. The capital realised the second smallest annual average growth (3.3\%) among the cities examined. As for the other five destinations, the compact size of the re- gion is both a blessing and a curse. The closeness of Brussels might generate extra visitor numbers in nearby cities including Bruges. However, it might also discourage overnight stays. The capital was followed by Antwerp, one of the largest port cities in Europe with 1.5 million nights in 2008, which grew to 1.8 million nights by 2012. The number of nights increased only moderately during the investigated period; in fact this city had by far the slightest increase in the number of nights, only 2.1 percent annual average growth was registered. Bruges came a close third realising 1.6 million nights in 2012 and the city enjoyed a dynamic expansion. The other three cities lagged far behind over the whole period, although the number of nights spent in Leuven and Mechelen rose annually by 6.7 and 6.0 percent respectively. All in all, the conclusion might be drawn that city tourism in Flanders has had great potentials and the trends suggest a further expansion in the future.

The lure of Bruges rests on three main factors: its heritage, cultural offerings and easy accessibility (Figure 1). Nemes Nagy, J. (2009) defines accessibility by the distance from the capital, from the closest regional centre, from the closest local centre, from the closest border checkpoint and from the closest highway. The canal-based city has a population of 120,000 and around 45,000 live in the medieval centre. It lies less than a hundred kilometres from Brussels and Antwerp and $40 \mathrm{~km}$ from Ghent. Bruges is connected by highways to all important settlements. Border checkpoints $(15 \mathrm{~km})$ do not have relevance within the European Union context; a mental border might exist for overseas tourists, though. The whole historic centre of Bruges has been a UNESCO World Heritage Site since 2000 and it was also the "European Capital of Culture" in 2002.

The development of quality tourism dates back to a conference held in 2002 (Sulyok, J. 2002), when the four principles of sustainability were defined: protecting cultural heritage, improving water quality, consensual city planning and efficient management of the 


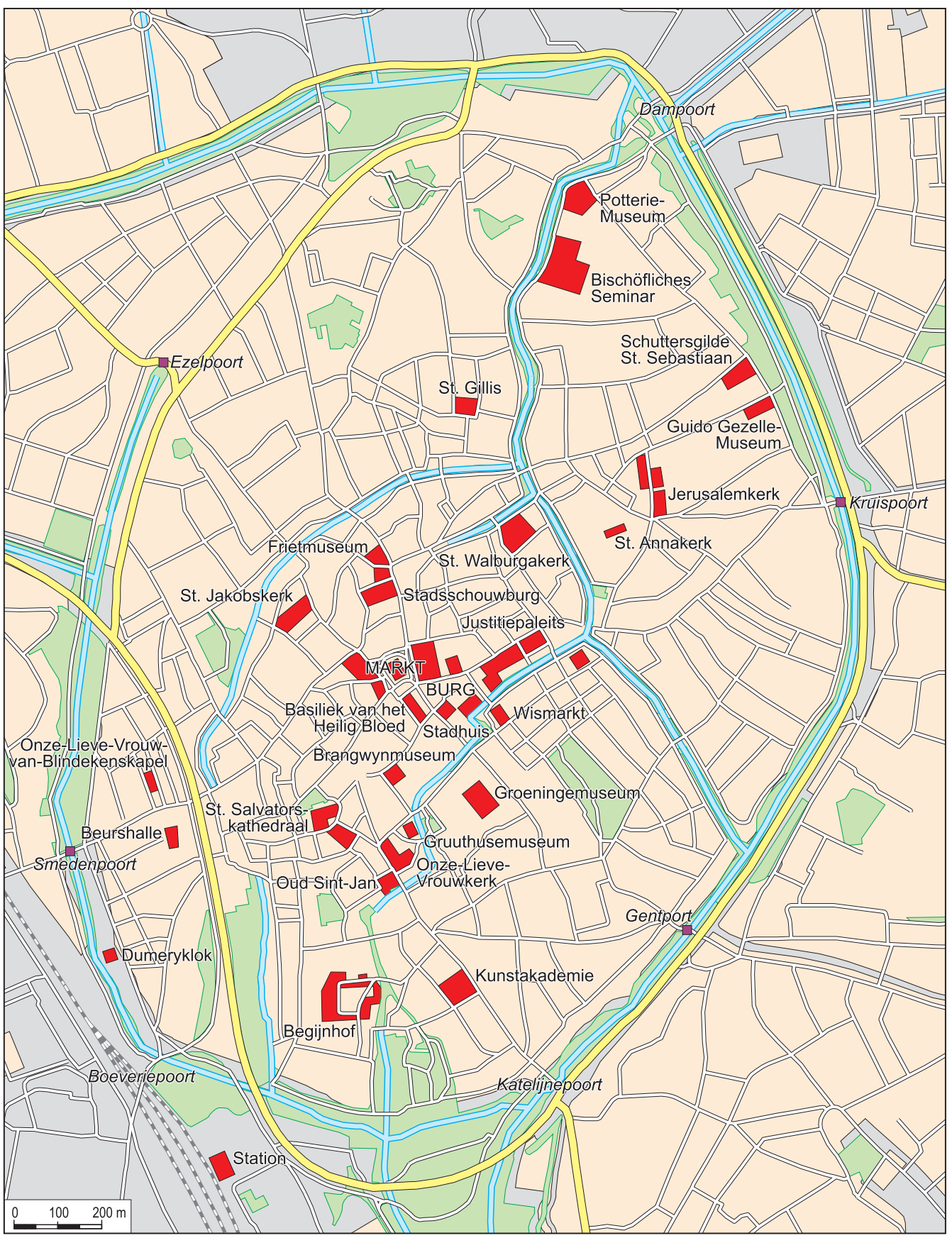

Fig 1. Main tourist attractions in the centre of Bruges. Source: http://www.planetware.com/ 
local community. Furthermore, recognising the need of mutual understanding between residents and visitors, the local government intended to improve both quality tourism and central areas heavily exposed to tourism concurrently. It also aimed to involve all stakeholders: service providers, tourists, tourism organisations, local residents and local government in order to find a consensual development path. Table 3 shows the main tourism data in Bruges between 2008 and 2012.

\section{Slow design elements in Bruges}

"Slow Design is a unique and vital form of creative activism that is delivering new values for design and contributing to the shift toward sustainability" - defined by STRAuss, C. and Fuad-Luke, A. (2008). The authors belong to the group of Slowlab, which is an organisation established to promote slow design. This initiative was inspired by the global slow movement and set similar aims:

Table 3. Tourism in the hotels of Bruges, 2008-2012

\begin{tabular}{|c|c|c|c|c|c|c|c|}
\hline \multirow{3}{*}{ Indicators } & \multicolumn{7}{|c|}{ Years } \\
\hline & \multirow[b]{2}{*}{2008} & \multirow[b]{2}{*}{2009} & \multirow[b]{2}{*}{2010} & \multirow[b]{2}{*}{2011} & \multirow[b]{2}{*}{2012} & \multicolumn{2}{|c|}{ Changes in $\%$} \\
\hline & & & & & & $\begin{array}{c}\text { from } 2011 \text { to } \\
2012\end{array}$ & $\begin{array}{c}\text { from } 2008 \\
\text { to } 2012\end{array}$ \\
\hline Guests & \multicolumn{7}{|c|}{ Number of arrivals in 1,000 persons } \\
\hline from abroad & 568.8 & 547.9 & 595.5 & 684.8 & 679.9 & -0.71 & 4.82 \\
\hline overall total & 691.4 & 675.0 & 753.8 & 859.7 & 866.7 & 0.82 & 6.04 \\
\hline Guests' nights & \multicolumn{7}{|c|}{ Number of overnight stays in 1,000 guest nights } \\
\hline from abroad & $1,086.5$ & $1,024.9$ & $1,096.4$ & $1,241.1$ & $1,245.1$ & 0.33 & 3.71 \\
\hline overall total & $1,276.9$ & $1,224.9$ & $1,347.1$ & $1,512.4$ & $1,529.2$ & 1.10 & 4.80 \\
\hline Average guests' days & \multicolumn{7}{|c|}{ Average length of stay in days } \\
\hline from abroad & 1.91 & 1.87 & 1.84 & 1.81 & 1.83 & 1.05 & -1.04 \\
\hline overall total & 1.85 & 1.82 & 1.79 & 1.76 & 1.77 & 0.29 & -1.13 \\
\hline
\end{tabular}

Source: Toerismevlaanderen 2013

The number of arrivals increased dynamically by 6 percent on average annually. More than 866,000 tourists stayed in hotels in the year of 2012. In terms of overnight stays in hotels, the city realized an annual average growth of 4.8 percent during the examined period, however, foreign visitors contributed more than domestic guests. In 2012 the total number of nights spent in hotels reached over 1.5 million

Looking at the average length of stay the picture is less promising. The growing number of tourists and overnight stays did not translate into longer stay per capita. Although there was a slight rebound from 2011 to 2012, the average annual fall in the average length of stay was more than 1 percent in case of both domestic and foreign hotel guests. they would like to provide alternatives to our fast-paced postmodern society in the field of design (www.slowlab.net). Besides the definition, authors also identified six main features that slow design has to possess. They are as follows:

Reveal: it reveals experiences in everyday life that are often missed or forgotten, including the materials and processes that can be easily overlooked in an artefact's existence or creation.

Expand: it considers the real and potential "expressions" of artefacts and environments beyond their perceived functionalities, physical attributes and lifespans.

Reflect: it induces reflective consumption.

Engage: it relies on sharing, co-operation and transparency of information so that designs may continue to evolve into the future. 
Participate: it encourages users to become active participants in the design process, embracing ideas of conviviality and exchange to foster social accountability and enhance communities.

Evolve: it recognises that richer experiences can emerge from the dynamic maturation of artefacts, environments and systems over time. Looking beyond the needs and circumstances of the present day, slow designs are (behavioural) change agents (Strauss, $\mathrm{C}$. and FuAd-LuKe, A. 2008).

The slow design concept elaborated by the authors includes elements that have been expected from good, user-friendly architecture and urban design; therefore, several old landscape solutions and structures in Bruges can be easily qualified as slow design. Below is a table featuring various design elements facilitating slowness in Bruges (Table 4). Sometimes slow design elements are the main attraction (lake), in other cases they are ancillaries (benches) enabling the full enjoyment of the place. serves as the natural, sound-proof buffer zone that enables visitors to slip into timeout mood and become more in synch with the environment.

According to Fórián, S. and Hagymássy, Z. (2009) green spaces in urban setting have primarily an air cleaning role, however, in tourism context their role expands way beyond that, including a recreational and an aesthetic role that is experienced through seeing, hearing and smelling. The interpretation of this sensory overload needs active participation from tourists. As they proceed and get deeper into the park, reengagement with nature and the outdoors occurs. Gradually, nature takes over, and reveals itself through the different sizes, shapes, smells and surfaces of plants. Their greenness exudes peace and quiet and oozes freshness. The sounds of nature: the whispering woods, the still water and the chattering birds provide visitors an acute sense of belonging and selfawareness, and the artificial efficiency of the railway station and the clock-time schedule

Table 4. Main touristic places in Bruges with their natural and architectural slow design elements

\begin{tabular}{l|l|l}
\hline \multicolumn{1}{c|}{ Places } & \multicolumn{1}{|c}{ Attractions } & \multicolumn{1}{c}{ Slow design elements } \\
\hline Minnewater park & Begina cloister, lake & green spaces, lake, bridges, flora and fauna \\
Canals & waterfront, canal cruise, guide's narrative & waterfront, bridges \\
Quays & waterfront, canal, water & waterfront, bridges, benches \\
Squares & monuments & passages, tower \\
\hline
\end{tabular}

Source: Author's compilation, 2014.

Time and space frame each tourist experience. Even though tourists can leave their clock-time regime behind (Dickinson, J.E. et al. 2013), they often need encouragement to change and revise their spatial-temporal plans and find their tempo giusto (Petrini, C. 2007). Urban design can definitely help with their readjustments. Next I go through all the slow design elements identified and included in Table 4, and analyse them using the 6 main features listed by Slowlab. For visitors in Bruges the railway station functions as the main gate of the city: close enough to walk to the centre but far enough to interfere with the rhythm pattern of the city. Between the centre and the station Minnewater Park become a fading memory. The great asset of parks is their constant evolution even without any human intervention. The authors argue that green spaces represent a touristic value themselves and play a positive role in urban environment.

In Bruges the Minnewater Park is also home to the scenic Lake of Love and the Begina Cloister. The pairing of the natural feature with spirituality reinforces a kind of Zen-like feeling and encourages reflective thinking. Most tourists use the same path to leave the city, so the park frames the visitation and ensures the smooth transition from passengers into visitors and vice versa. As for its crowd management role, it forces people 
to change space and rhythm. As each person adjusts to a different extent, the park can easily absorb a full train of passengers who as a result reach the centre at different times.

Canals are defined by Fallon, J. (2012, p. 143) as "historical linear parks, serving as leisure space for boating and walking." In terms of the tourist gaze, canals and quays are in parallel relationship, therefore, offer similar possibilities. The key difference lies in the perspective and angle. They both have a compelling pull factor and take visitors away from the confined central area. In the past the role of waterways was mainly to speed up traffic, while in modern urban tourism waterways are usually slowing features. In Bruges canals are not served as public transportation anymore, so they are entirely for the consumption of visitors (Photo 1).

Although the canal trip is a compulsory tourist trap, it provides a more intimate, insider perspective and reveals angles that otherwise might have been hidden from the tourist gaze. Unpowered water transports like boat trips always mean slower pace and without the need of navigation and orientation, tourists have time to reflect and contemplate.

According to FAllon, J. (2012) slowness is synonymous with canals and in many countries there is a speed limit of four miles per hour as not to make waves. In Bruges only a single type of trip is available and departure is possible from 5 points and the boat returns to the same point without a halt. Due to the well-regulated supply - in terms of the number of boats and frequency - the tourist flow is more predictable and evenly distributed. The uniformity of boats and umbrellas (provided in case of rain) ensure a harmoniously blended environment, thus, enhances aesthetic pleasure. The sailors/guides' narration expands knowledge and invites engagement and participation in the common narrative creation.

Waterfronts with bridges and benches form an ideal slow design mix and contribute to slowing down and breaking the rhythm of walking. The waterfront along the

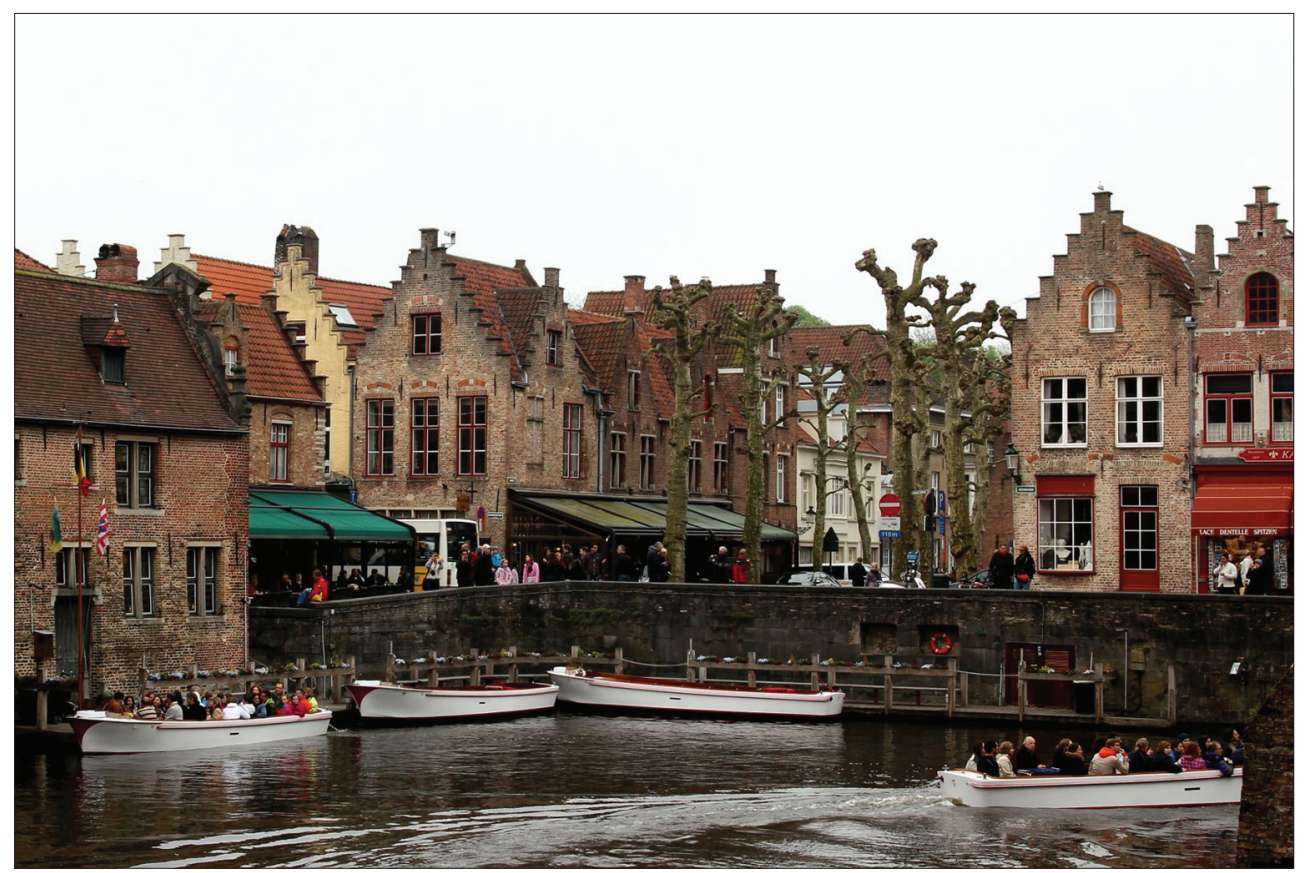

Photo 1. Tourists enjoying canal trips in the heart of Bruges 
five-km long quay is the key feature in the Hansa town, home to the most sought-after real estates and landmarks. Therefore, waterfronts with their distinctive atmosphere are always a drawcard for both locals and tourists. During the stroll, buildings reveal their intricate details and ornamentations, by sneaking into courtyards walkers enjoy a more intimate and personal sense of the place. Reading the plaques on the facades promotes a joy of learning and engages visitors to recall and expand their school knowledge. Blending the old and new knowledge together, a deeply personal narrative evolves. As opposed to the canal trip, strollers are free to choose their own walking speed and can take advantage of the benches placed at regular intervals for their convenience. Bridges and benches both invite visitors to pose and reflect. Watching the water full of uniform boats with the Hansa architecture at the backdrop provides a reflective and sharing mood. Bridges expand way beyond their functionality by revealing new angles and perspectives, if strollers stand in the middle. They offer a wider horizon, and inspire people to come up with their own zoom-ins and individual interpretations of the scenery.

In the city centre different solutions are necessary to manage the tourist flow. The two primary squares of the centre are the Markt and the Burg; both are accessed via Steenstraat, the main street of the city. It is a relatively narrow street with plenty of passages giving visitors the chance of leaving the crowd behind and revealing hidden corners. These in-between places coupled with the commercial facilities available allow tourists the dichotomy of mobility/immobility (Deleuze, G. and Guattari, F. 2003), while they engage and participate in window shopping and/or retail activity. Thanks to these detours and diversions tourists might take a day to finally reach the main square, which is home to a collection of historic buildings, representing almost every era in the history of the city: the gothic Town Hall, the renaissance Holy Blood Basilica, the Old Civil Majesty and the Bishop's palace. Further, the
Market Square features two other landmarks: the Belfry tower and the Provincial Court. These flagship monuments offer some interesting historical and cultural insights to expand knowledge and reflect upon.

Horizontal scattering of tourists on main squares jam-packed with sights is bordering on the mission impossible. In these cases vertical structures such as church towers offer the chance of slowing down pace. The Belfry tower in Bruges has 366 stairs and enjoying the view at the top is the highlight of each city break. Towers are classical slow structures and their biggest advantage lies in the unavoidable and arduous climbing that is necessary to access the panoramic view at the top. So, towers are the most engaging and participatory of all urban attractions, and most visitors take up the challenge. What is so alluring, then? The combination of the climb, the anticipation and finally the view together create such memorable experiences that are worth remembering. The city reveals a kind of postcard image unattainable elsewhere and expands visitors' horizons in every sense of the word. The sky-perspective gives the sum total of all the mosaic experiences gained on the ground. The view evolves not only as a result of the changes in the urban architectural pattern but the city also offers new visual possibilities at different times of the day, season, and year, which encourages repeat viewing.

The above discussed natural and manmade structures provide ideal conditions for slow tourism in urban setting not only because they slow down pace but the experience gained is characterised by less travel, lower carbon consumption and exploration of local culture and patrimony, all included in the slow tourism concept identified by Dickinson, J.E. et al. (2010).

\section{Conclusion}

In this paper we examined the link between the tourist flow and urban planning solutions as well as the way the latter might contribute 
to slowing down city tourists and dispersing them more evenly in urban areas. The natural and man-made design elements were explained by using the six main features of slow design defined by Strauss, C. and FuAd-Luke, G. (2008). Then, the question was explored how the various urban solutions including green spaces, land and water related structures influence the tourist flow by slowing down pace and enforcing rhythm change. We argue that even historic cities as Bruges with a large number of visitors have design tools in order to redistribute tourists. As a result, visitors leave with more memorable experiences while locals get on with their life with less interference by tourists. The study ultimately aimed to bring together all stakeholders and open an intellectual dialogue on potential design tools to help urban destinations cope successfully with spatial and temporal management of the tourist flow. Further studies should aim to explore the demand side of slow urban tourism, which would give a clearer idea in terms of development and fine-tuning of slow design elements in popular urban destinations.

\section{REFERENCES}

Biczó, G. 2011. A hely és a reprezentáció (The place and the representation). In Szinre vitt helyek. Ed.: Fejős, Z. Budapest, Néprajzi Múzeum, 7-17.

Bryon, J. 2005. De Dialectische Relatie tussen Stadbewoners en de Toeristischstedelijke Ruimte. Case Study: Bruges. Unplublished Ph.D Thesis. Leuven, Katholieke Universitet Leuven.

Bryon, J. and Neuts, B. 2008. Crowding and the Tourist Experience in an Urban Environment: a Structural Equation Modelling Approach. http://www.steunpunttoerisme.be/main/files/nieuwsbrief/oktober_2008/paperNVVS_bart_neuts.pdf 1-14. (15 June 2013).

Deleuze, G. and Guattari, F. 2003. A Thousand Plateaus: Capitalism and Schizophrenia. Minnesota, University of Minnesota Press, 632 p.

Dickinson, J.E., Lumsdon, D. and Robbins, D.K. 2010. Slow Travel: Issues for Tourism and Climate Change. Journal of Sustainable Tourism 19. (3): 281-300.

Dickinson, J.E., Robbins, D., Filimonou, V., Hares, A. and Mika, M. 2013. Awareness of Tourism Impacts on Climate Change and the Implications for Travel Practice: A Polish Perspective. Journal of Travel Research 52. (4): 506-519.
Fallon, J. 2012. If You Are Making Waves then You Have to Slow down: Slow tourism and Canals. In Slow Tourism: Experiences and Mobilities. Eds.: Fullagar, S. et al. Bristol, Channel View, 143-154.

FóriáN, S. and Hagymássy, Z. 2009. Zöldfelületek szerepe az urbanizált környezetben (The role of green surfaces in urbanized environs). Debreceni Müszaki Közlemények 1-2. http://www.eng.unideb. hu/userdir/dmk/docs/20091/09_1_05.pdf (20 June 2013).

Honoré, C. 2005. In Praise of Slowness. New York, HarperCollins, 288 p.

Jensen, O.B. 2009. Flows of Meaning, Cultures of Movements Urban Mobility as Meaningful everyday Life Practice. Mobilities 4. (1): 139-158.

Knox, P. 2005. Creating Ordinary Places: Slow Cities in a Fast World. Journal of Urban Design 1. 1-11.

Lumsdon, L. and McGrath, P. 2010. Developing a Conceptual Framework for Slow Travel: a Grounded Theory Approach. Journal of Sustainable Tourism 3. 265-279.

Michalkó, G. 2012. Turizmológia (Tourismology). Budapest, Akadémiai Kiadó, 206 p.

Michalkó, G. and RÁtz, T. 2006. The Mediterranean Tourist Milieu. Anatolia: An International Journal of Tourism and Hospitality Research 17. (1): 93-109.

Nemes, Nagy J. 2009. Terek, helyek, régiók. A regionális tudomány alapjai. (Spaces, places regions. Bases of regional science). Budapest, Akadémiai Kiadó, 350 p.

Niedermüller, P. 2000. Városi turizmus. Történelem, művészet, egzotikum (Urban tourism. History, art, egzotics). In Turizmus és kommunikáció. Eds.: Fejôs, Z. and SzıjÁrtó, Zs. Budapest, Néprajzi Múzeum. 31-38.

Oldfield, P. 2013. Középkori turizmus (Medieval tourism). BBC History 3. 50-55.

Petrini, C. 2007. Slow Food Nation: Why Our Food should be Good, Clean and Fair? New York, Rizzoli Ex Libris, 304 p.

Pine, P.J. and Gilmore, J.H. 1999. The Experience Economy. Boston, Harvard University Press, 470 p.

Popp, M. 2012. Positive and Negative Urban Tourist Crowding: Florence, Italy. Tourism Geographies: An International Journal of Tourism Space, Place and Environment 14. (1): 50-72.

Puczkó, L. and RÁtz, T. 2003. Turizmus történelmi városokban. Tervezés és menedzsment (Tourism in historical towns. Planning and management). Budapest, Turisztikai Oktató és Kutató Kkt, 111 p.

Selby, M. 2004. Consuming the City: Conceptualizing and Researching Urban Tourist Knowledge. Tourism Geographies 6. (2): 186-207.

Senneth, R. 1994. Flesh and Stone. The Body and the City in Western Civilization. New York, W.W. Norton and Company.

Strauss, C. and Fuad-Luke, G. 2008. The Slow Design Principles. 1-14. http://www.slowlab.net/CtC_ SlowDesignPrinciples.pdf (2 January 2014. 
Sulyoк, J. 2002. Brugge. http://itthon.hu/site/upload/mtrt/Turizmus_Bulletin/02_03/Tu-Re30.htm (8 June 2013)

SZIJÁRTó, Zs. 2011. Turisták, bárhol - a városi turizmusról (Touristst anywhere - about urban tourism). In Szinre vitt helyek. Ed.: Fejős, Z. Budapest, Néprajzi Múzeum.171-176.

UNWTO, 2002. Tourism Vision 2020.

UNWTO, 2013. Global Report on City Tourism 2012. http://dtxtq4w60xqpw.cloudfront.net/sites/all/files/ pdf/am6_city_platma.pdf (20 June 2013.
WHO, 2014. Urban Population Growth, 2014. http:// www.who.int/gho/urban_health/situation_trends/ urban_population_growth_text/en/ (30 June 2014).

Homepages: www.cittaslow.com, www.euromonitor. org, www.planetware.com, www.slowfood.com, www.slowlab.net, www.toerismevlaanderen.fl 